Keywords: collagen Type XI $\alpha 1$; head and neck squamous cell carcinoma; invasion; cancer-associated fibroblasts; tumour progression; extracellular matrix proteins

\title{
Collagen type XI $\propto 1$ facilitates head and neck squamous cell cancer growth and invasion
}

\author{
J C Sok ${ }^{1,5,6}$, J A Lee ${ }^{1,5}$, S Dasari ${ }^{1}$, S Joyce ${ }^{1}$, S C Contrucci ${ }^{1}$, A M Egloff ${ }^{1,2}$, B K Trevelline ${ }^{1}$, R Joshi ${ }^{1}$, N Kumari ${ }^{1}$, \\ J R Grandis ${ }^{1,3}$ and S M Thomas ${ }^{\star, 4}$ \\ ${ }^{1}$ Department of Otolaryngology, University of Pittsburgh and University of Pittsburgh Cancer Institute, Pittsburgh, PA 15213, USA; \\ ${ }^{2}$ Department of Microbiology \& Molecular Genetics, University of Pittsburgh and University of Pittsburgh Cancer Institute, \\ Pittsburgh, PA 15213, USA; ${ }^{3}$ Department of Pharmacology \& Chemical Biology, University of Pittsburgh and University of \\ Pittsburgh Cancer Institute, Pittsburgh, PA 15213, USA and ${ }^{4}$ Department of Otolaryngology, University of Kansas Medical Center, \\ Kansas City, KS 66160, USA
}

Background: Although it is well established that the extracellular matrix affects tumour progression, not much is known about the various components and their effect on head and neck squamous cell carcinoma (HNSCC) progression. Levels of collagen type XI $\alpha 1$ (colX| 1 1), a minor fibrillar collagen, have been shown to be increased in tumour compared with normal tissue in several cancers, including colorectal, breast, and non-small cell lung cancer. Currently, the functional significance of colXI 1 is not understood.

Methods: We examined the expression levels of colXI $\alpha 1$ mRNA and elucidated the functional role of colXI $\alpha 1$ in HNSCC. Cell proliferation, invasion, and migration were examined with and without colXl 1 knockdown with siRNA in HNSCC cells.

Results: Our data demonstrate that co|X| 1 expression is increased in tumour samples compared with levels in normal adjacent tissue in 16/23 HNSCC patients. In addition, col 111 is increased in HNSCC cell lines compared with normal immortalised epithelial cells and is increased in tumour-derived fibroblasts compared with normal fibroblasts. Using an siRNA approach, we demonstrate that colXI 1 contributes to proliferation, migration, and invasion of HNSCC.

Conclusion: Our cumulative findings suggest that colXI $\alpha 1$ contributes to HNSCC tumorigenesis and may serve as a potential therapeutic target.

Worldwide, head and neck cancer is the 6th leading cause of cancer mortality, with 350000 deaths per year due to cancers of the oral cavity, pharynx, and larynx (Ferlay et al, 2008). Over 630000 new cases of head and neck cancer are diagnosed annually, of which 90\% are squamous cell carcinoma (HNSCC). Treatment with standard modalities, including chemotherapy, radiation, and surgery, is associated with a 5 -year survival rate of only $50 \%$, emphasising the need for newer, more effective approaches (Cognetti et al, 2008). Although cumulative evidence supports the epidermal growth factor receptor (EGFR) as a therapeutic target in HNSCC, where increased expression correlates with worse prognosis (Rubin Grandis et al, 1998), treatment with the EGFRtargeted monoclonal antibody cetuximab has not been shown to prevent metastasis (Bonner et al, 2006).
In a previous study, we used a 12000 gene oligonucleotide microarray of paired tumour and normal tissue from nine HNSCC patients to determine differential gene expression in order to identify potential therapeutic targets (Sok et al, 2003). Gene expression changes were found in 227 genes, including collagen type XI subunit $\alpha 1$ (colXI $\alpha 1$ ), which was found in all nine tumours with virtually no expression in normal tissue.

Type XI collagen, a minor fibrillar collagen, is a heterotrimer composed of $\alpha 1, \alpha 2$, and $\alpha 3$ chains that co-polymerise with type II and IX collagen to form the cartilage (Spranger, 1998). The $\alpha 1$ subunit produced by non-cartilaginous tissues, such as bone, skin, and arterial smooth muscle cells, is located on chromosome 1 and regulates the promoter of the major collagen type V (COL5a2) (Yoshioka et al, 1995). Although type XI collagenopathies at birth

\footnotetext{
*Correspondence: Dr SM Thomas; E-mail: sthomas7@kumc.edu

${ }^{5}$ These authors contributed equally to the work.

${ }^{6}$ Present address: Department of Otolaryngology-Head and Neck Surgery, Loma Linda University School of Medicine, Loma Linda, CA, USA
}

Received 19 April 2013; revised 11 September 2013; accepted 18 September 2013; published online 14 November 2013 
are known to produce phenotypes that include facial anomalies, cleft palate, and hearing defects (Spranger, 1998), relatively little is known about the function of type XI collagen in the adult.

A 2001 study of colorectal tumours first identified an association between colXI $\alpha 1$ and cancer (Fischer et al, 2001b). ColXI $\alpha 1$ mRNA expression was found in 20 of 24 colorectal tumours, whereas no apparent expression was found in the 4 normal tissue samples. In addition, COL5a2, which is normally expressed in human fetal gut and not expressed in the normal adult colon tissue, was correlated with the expression of colXI $\alpha 1$ in the colorectal tumours. Recent studies in several other areas of cancer research, including gastric (Vecchi et al, 2007; Zhao et al, 2009), pancreatic (Badea et al, 2008), breast (Ellsworth et al, 2009), and non-small lung cancer (Chong et al, 2006), have also demonstrated increased levels of colXI $\alpha 1$ in tumour tissue compared with less-diseased or normal tissue. In a multi-cancer computational analysis of four data sets of ovarian and colorectal cancer, the authors concluded that $\operatorname{colXI} \alpha 1$ overexpression is a proxy for 'metastasis-associated fibroblast (MAF)' signature (Kim et al, 2010).

Our initial observation of increased expression of $\operatorname{colXI} \alpha 1$ in HNSCC was corroborated by another group whose findings also implicated colXI $\alpha 1$ in the pathogenesis of HNSCC metastasis to the lymph nodes (Schmalbach et al, 2004). Primary tumours that had metastasised to the lymph nodes demonstrated over seven-fold higher expression of colXI $\alpha 1$ than tumours that had not metastasised and over 25 -fold higher expression of $\operatorname{colXI} \alpha 1$ than levels in normal oral cavity mucosa samples. Thus far, the precise role of colXI $\alpha 1$ in proliferation and invasion remains incompletely understood, and few functional data have been reported.

In the present study, we examined colXI $\alpha 1$ expression in a panel of HNSCC cell lines and a cohort of paired tumour/normal samples derived from HNSCC patients. We then used an siRNA approach to determine the role of $\operatorname{colXI} \alpha 1$ in cellular proliferation, migration, and invasion.

\section{MATERIALS AND METHODS}

Cell lines, tumours, and reagents. Human HNSCC cell lines included UMSCC-1 (Krause et al, 1981), UMSCC-10A (Grenman et al, 1991), UMSCC-10B (Somers et al, 1992), UMSCC-22A (Lansford et al, 1999), and UMSCC-22B (Grenman et al, 1991), which were kind gifts from Dr. Thomas Carey (University of Michigan); UPCI-15B (Snyderman et al, 1994) from Dr. Theresa Whiteside (University of Pittsburgh); 1483 (Sacks et al, 1988) from Dr. Peter Sacks (New York University); 686LN (Sturgis et al, 1994) from Dr. Georgia Chen (Emory University); and FaDu (Rangan, 1972) from Dr. Jeffrey Myers (The University of Texas MD Anderson Cancer Center). The Het1A (Stoner et al, 1991) cell line, derived from mucosal epithelial cells, was obtained from American Type Culture Collection (Manassas, VA, USA). All cell lines were validated through genotyping with an AmpF/STR Identifiler PCR Amplification Kit (Applied Biosystems, Carlsbad, CA, USA).

UMSCC-1 and FaDu cells were maintained in Dulbecco's modified Eagle's medium (DMEM; Invitrogen, Carlsbad, CA, USA) with $10 \%$ heat-inactivated fetal bovine serum (FBS; Invitrogen) and $0.4 \mu \mathrm{lml}^{-1}$ hydrocortisone. 686LN cells were maintained in Dulbecco's modified Eagle's medium/F12 (1:1) (Invitrogen) and 10\% FBS. Het1A cells were maintained in Airway Epithelial Cell Growth Media (PromoCell, Heidelberg, Germany) with a supplement provided by the company. All other cell lines including cancer-associated fibroblasts (CAFs), and normal fibroblasts were maintained in DMEM with 10\% FBS. All cells were incubated at $37^{\circ} \mathrm{C}$ in the presence of $5 \% \mathrm{CO}_{2}$. Fibroblast cultures were growth from HNSCC tissue or from uvulopalatoplasty or tonsil explants from cancer-free subjects. Written consent was collected from patients, using a University of Pittsburgh, Institutional Review Board approved protocol. In brief, tissue pieces were minced and placed in $10 \%$ serum containing media. Fibroblast cultures free of epithelial cells were used in these studies.

Primary HNSCC tumour samples, as well as normal mucosal samples adjacent to the tumour site, were obtained under an institutional review board-approved protocol from 23 HNSCC patients undergoing surgical excision with curative intent (Table 1). Signed informed consent was obtained from each subject. Human papilloma virus (HPV) status was not determined for majority of the patients (58\%). All evaluated patients were HPV negative.

\begin{tabular}{|c|c|}
\hline Characteristic & HNSCC cases $(\mathbf{N}=23)$ \\
\hline \multicolumn{2}{|l|}{ Age, years } \\
\hline Median (range) & $63(32-88)$ \\
\hline \multicolumn{2}{|l|}{ Sex, $\mathbf{N}(\%)$} \\
\hline $\begin{array}{l}\text { Men } \\
\text { Women }\end{array}$ & $\begin{array}{r}17(73.9) \\
6(26.1)\end{array}$ \\
\hline \multicolumn{2}{|l|}{ Smoking, $\mathbf{N}(\%)$} \\
\hline $\begin{array}{l}\text { Never } \\
\text { Former Smoker } \\
\text { Active Smoker }\end{array}$ & $\begin{array}{c}2(8.7) \\
8(34.8) \\
13(56.5)\end{array}$ \\
\hline \multicolumn{2}{|l|}{ Alcohol, $\mathbf{N}(\%)$} \\
\hline $\begin{array}{l}\text { Never } \\
\text { Ever }\end{array}$ & $\begin{array}{r}8(34.8) \\
15(65.2)\end{array}$ \\
\hline \multicolumn{2}{|l|}{ Cancer site, $\mathbf{N}(\%)$} \\
\hline $\begin{array}{l}\text { Oral cavity } \\
\text { Pharynx } \\
\text { Larynx } \\
\text { Other }\end{array}$ & $\begin{aligned} 16 & (79.6) \\
1 & (4.3) \\
4 & (17.4) \\
2 & (8.7)\end{aligned}$ \\
\hline \multicolumn{2}{|l|}{ Cancer type, $\mathbf{N}(\%)$} \\
\hline $\begin{array}{l}\text { Primary } \\
\text { Recurrence }\end{array}$ & $\begin{array}{r}20(87.0) \\
3(13.0)\end{array}$ \\
\hline \multicolumn{2}{|l|}{ Tumour path stage, $\mathbf{N}(\%)$} \\
\hline $\begin{array}{l}\text { T1-T2 } \\
\text { T3-T4 } \\
\text { Unstaged recurrent tumour }\end{array}$ & $\begin{array}{r}8(34.8) \\
12(52.2) \\
3(13.0)\end{array}$ \\
\hline \multicolumn{2}{|l|}{ Nodal path stage, $\mathbf{N}(\%)$} \\
\hline $\begin{array}{l}\text { NO-N1 } \\
\text { N2-N4 } \\
\text { Unstaged recurrent tumour }\end{array}$ & $\begin{array}{r}12(52.2) \\
8(34.8) \\
3(13.0)\end{array}$ \\
\hline \multicolumn{2}{|l|}{ Perineural invasion, $\mathbf{N}(\%)$} \\
\hline $\begin{array}{l}\text { Yes } \\
\text { No } \\
\text { Not evaluated }\end{array}$ & $\begin{aligned} 14 & (60.9) \\
7 & (30.4) \\
2 & (8.7)\end{aligned}$ \\
\hline \multicolumn{2}{|l|}{ HPV, $\mathbf{N}(\%)$} \\
\hline $\begin{array}{l}\text { Positive } \\
\text { Negative } \\
\text { Not evaluated }\end{array}$ & $\begin{array}{c}0(0.0) \\
9(39.1) \\
14(60.9)\end{array}$ \\
\hline
\end{tabular}


RT-PCR analysis for colXI $\alpha 1$. Total RNA was isolated from $30 \mathrm{mg}$ of snap-frozen tumour tissue as described previously using an RNeasy Mini kit (Qiagen, Valencia, CA, USA) (Sok et al, 2003). One nanogram of total RNA was added to a final reaction volume of $25 \mu \mathrm{l}$. To detect colXI $\alpha 1$, standard RT-PCR was done using a One-Step RT-PCR kit (Qiagen) with primers (5'-GGATCAAA TGATGAGGAGATGTCCTATG- $3^{\prime}$ and antisense sequence as 5'-CTAAATGGTACCTGTATATGCAGCGTTG-3') designed to amplify a 345 -bp fragment. Actin primers were used as previously described (Sok et al, 2006). Primers were diluted to a final concentration of $0.6 \mu \mathrm{M}$. All other reagents were used according to the manufacturer's protocol. Reverse transcription was performed at $50{ }^{\circ} \mathrm{C}$ for $30 \mathrm{~min}$, followed by enzyme inactivation and PCR hot start at $95{ }^{\circ} \mathrm{C}$ for $15 \mathrm{~min}$. Denaturation, annealing, and extension were performed at $94^{\circ} \mathrm{C}, 55^{\circ} \mathrm{C}$, and $72^{\circ} \mathrm{C}$, respectively, for $1 \mathrm{~min}$ each for a total of 35 cycles. The reaction was completed with an extension period at $72{ }^{\circ} \mathrm{C}$ for $10 \mathrm{~min}$. PCR products were visualised on a $1 \%$ agarose gel containing ethidium bromide. Expression levels of colXI $\alpha 1$ and actin in the paired tumour and normal epithelial samples were compared using ImageJ densitometry software.

Total RNA was isolated from $5 \times 10^{6}$ cells from each of the nine representative HNSCC cell lines (UMSCC-1, UMSCC-10A, UMSCC-10B, UMSCC-22A, UMSCC-22B, UPCI-15B, 1483, $686 \mathrm{LN}$, and $\mathrm{FaDu}$ ), normal mucosal epithelial cell line Het1A $\left(5 \times 10^{6}\right.$ cells), and fibroblasts, using an RNeasy Mini kit (Qiagen). RT-PCR to detect colXI $\alpha 1$ was performed as described above.

ColXI $\alpha 1$ siRNA transfection. Four different siRNA duplexes (A-D) targeted against human colXI $\alpha 1$ mRNA were generated according to the Assays-on-Demand system (Dharmacon, Lafayette, CO, USA): duplex (A) GCAAAUUGGUGUUGAGGUU UU, duplex (B) GAACGUGGGUCAGCAGGUAUU, duplex (C) AAAGGGACAUCCUGGUUUAUU, duplex (D) UCUGGUAGA UGGAGAUUUAUU. Pooled siRNA-colXI $\alpha 1$ was formed by combining all four duplexes. One day before transfection, UPCI$15 \mathrm{~B}$ cells were plated at $0.5 \times 10^{4}$ cells into 24 -well plates in order to attain $80-90 \%$ confluency at the time of transfection. Twentypicomole siRNA was transfected in cells with Lipofectamine 2000 (Invitrogen, Carlsbad, CA) in Opti-MEM media.

In vitro growth inhibition by colXI $\alpha 1$ siRNA. To examine the effects of colXI $\alpha 1$ on growth kinetics, UMSCC1 cells were treated with colXI $\alpha 1$ siRNA B or control non-targeting siRNA. Around $42 \mathrm{~h}$ post transfection, the cells were trypsinised and plated in xCelligence E-plates Roche (Indianapolis, IN, USA) as previously described (Hickok et al, 2011). In brief, after baseline measurements, 2000 cells were plated in $200 \mu \mathrm{l}$ DMEM $+10 \%$ FBS in quadruplicates into 16-well E-plates. Cell index (difference between the impedance at a given time point and the background, divided average resistance across the plate in media only using $10 \mathrm{kHz}$ frequency of current) measurements were taken every $15 \mathrm{~min}$. The growth rates of the cells were assessed in real-time over $40 \mathrm{~h}$ on the xCelligence DP system. The fold-change in growth relative to the measurement at $5 \mathrm{~h}$ post plating was determined. The experiment was repeated three independent times.

Matrigel invasion assay and migration assay. Cell invasion was evaluated in vitro using Matrigel-coated semipermeable-modified Boyden inserts with a pore size of $8 \mu \mathrm{m}$ (Becton Dickinson/Biocoat, Bedford, MA, USA). Cell migration was evaluated in vitro using semipermeable-modified Boyden inserts with a pore size of $8 \mu \mathrm{m}$ (Becton Dickinson/Biocoat). Cells from HNSCC lines (UMSCC-1 and $\mathrm{FaDu}$ ) and the normal cell line Het1A were transfected with siRNA-colXI $\alpha 1$ duplex B or non-targeting control siRNA (siRNANTC) as described above and plated in duplicate at a density of $1.25 \times 10^{4}$ cells per well in serum-free media in the insert. The insert contained serum-free media, while the holding well contained $10 \%$ FBS that served as a chemoattractant. After $24 \mathrm{~h}$ of treatment at $37^{\circ} \mathrm{C}$ in a $5 \% \mathrm{CO}_{2}$ incubator, the cells in the insert were removed by gentle wiping with a cotton swab. Cells on the reverse side of the insert were fixed and stained with Hema 3 (Fisher Scientific, Hampton, NH, USA) according to the manufacturer's instructions. Cells plated in 24-well plates were subjected to 3-(4,5-dimethylthiazol-2-yl)-2,5-diphenyltetrazolium bromide (MTT) assays, and the cell numbers across the groups were normalised. A ratio of the number of invading/migrating cells to the OD from the MTT assay was determined in order to adjust for changes in cell number across wells.

Statistical analysis. Non-parametric, Wilcoxon-Mann-Whitney exact tests were used to compare effects on cell proliferation, invasion, and migration in cells treated with control or colXI $\alpha 1$ siRNA. In order to analyse the differences between levels of $\operatorname{colXI} \alpha 1$ in the paired tumour and normal adjacent mucosa tissue samples from 23 patients, the exact Wilcoxon Signed rank test was used. All statistical analyses were performed with Cytel Studio 9 (Cytel, Inc., Cambridge, MA, USA).

\section{RESULTS}

Increased expression of colXI $\alpha 1$ in HNSCC tumours compared with levels in adjacent normal mucosa. Previous cDNA microarray analysis demonstrated that, although $\operatorname{colXI} \alpha 1$ was present in tumour tissue from all nine HNSCC tumours examined, it was virtually undetectable in corresponding normal adjacent tissue (Sok et al, 2003). The high incidence of synchronous and metachronous tumours of the upper aerodigestive tract that characterises HNSCC carcinogenesis suggests that molecular changes that are found in both the tumour and adjacent normal mucosa may represent relatively early genetic changes (Bedi et al, 1996; Scholes et al, 1998). We sought to determine colXI $\alpha 1 \mathrm{mRNA}$ levels in tumour tissue compared with levels in paired adjacent normal tissue in 23 HNSCC patients using RT-PCR. In 16 of 23 pairs, colXI $\alpha 1$ expression was significantly higher in the tumour compared with normal tissue $(P=0.0006)$ with a median fold increase of 6.63 (range 1.8-169), suggesting that increased $\operatorname{colXI} \alpha 1$ represents a later event in HNSCC carcinogenesis (Figure 1). In the absence of specific antibodies of sufficiently high quality, we could not validate these expression results at the protein level. However, our results confirm earlier studies demonstrating increased expression of colXI $\alpha 1$ in HNSCC tumours.

Increased expression of colXI $\alpha 1$ in HNSCC cell lines compared with normal immortalised mucosal epithelial cells. Tumour lysates represent both epithelial and stromal cells in the tumour microenvironment. There are no reports of colXI $\alpha 1$ expression in cancer cell lines compared with corresponding normal cells. To determine if the transformed epithelial cells were the likely source of colXI $\alpha 1$ lines, we compared colXI $\alpha 1$ mRNA levels in nine genotypically validated, representative HNSCC cell lines (UMSCC-1, UMSCC-10A, UMSCC-10B, UMSCC-22A, UMSCC22B, UPCI-15B, 1483, 686LN, and $\mathrm{FaDu}$ ) with expression levels in immortalised normal mucosal epithelial cells (Het1A) by RT-PCR. Expression of colXI $\alpha 1$ was detected in all nine HNSCC cell lines examined compared with the corresponding normal cell line, which did not express colXI $\alpha 1$ transcript (Figure 2). These results suggest that $\operatorname{colXI} \alpha 1$ overexpression is, at least in part, due to increased expression in the transformed epithelial cell component of tumours.

Increased expression of colXI $\alpha 1$ in tumour-derived fibroblasts compared with fibroblasts from cancer-free subjects. It is well documented that, in response to wounds, normal fibroblasts secrete several types of collagen including colXI $\alpha 1$. Stromal 


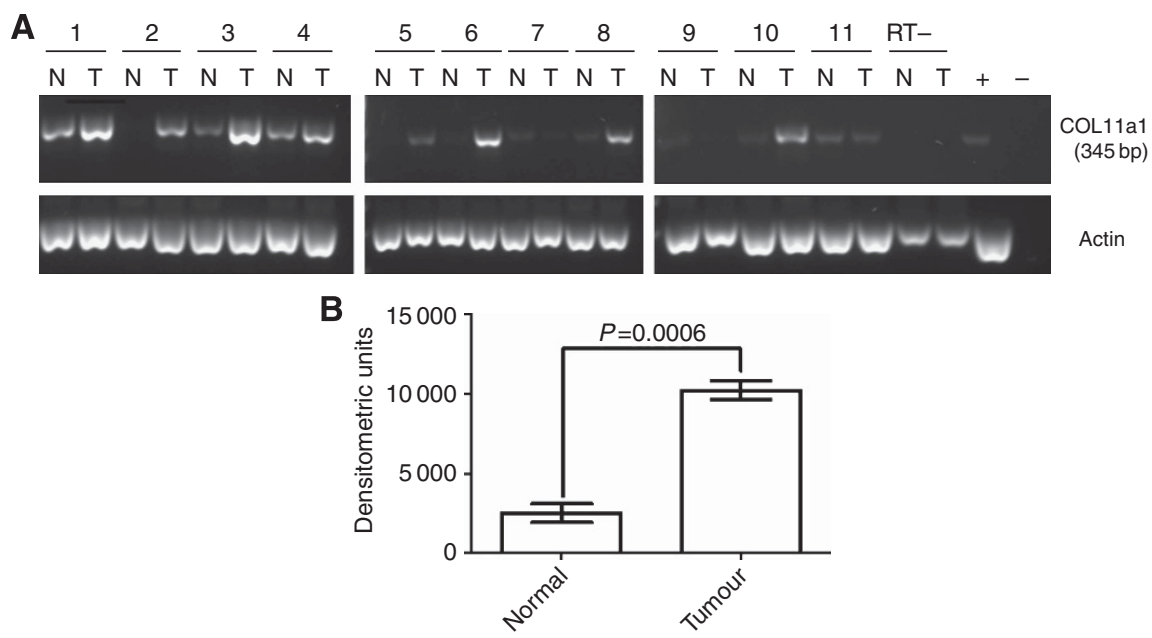

Figure 1. Increased expression of colXI $\alpha 1$ expression in HNSCC tumours compared with levels in normal mucosa. ColXl 1 mRNA levels were examined in 23 HNSCC tumour/normal pairs by RT-PCR. (A) Representative gel images from 11 patients are depicted. (B) Cumulative densitometric analyses of ColXl $\alpha 1$ and actin levels from 23 paired samples demonstrates significantly higher colXl $\alpha 1$ expression in 16 tumours compared with the paired normal adjacent mucosa $(P=0.0006)$. Error bars represent \pm s.e.m.

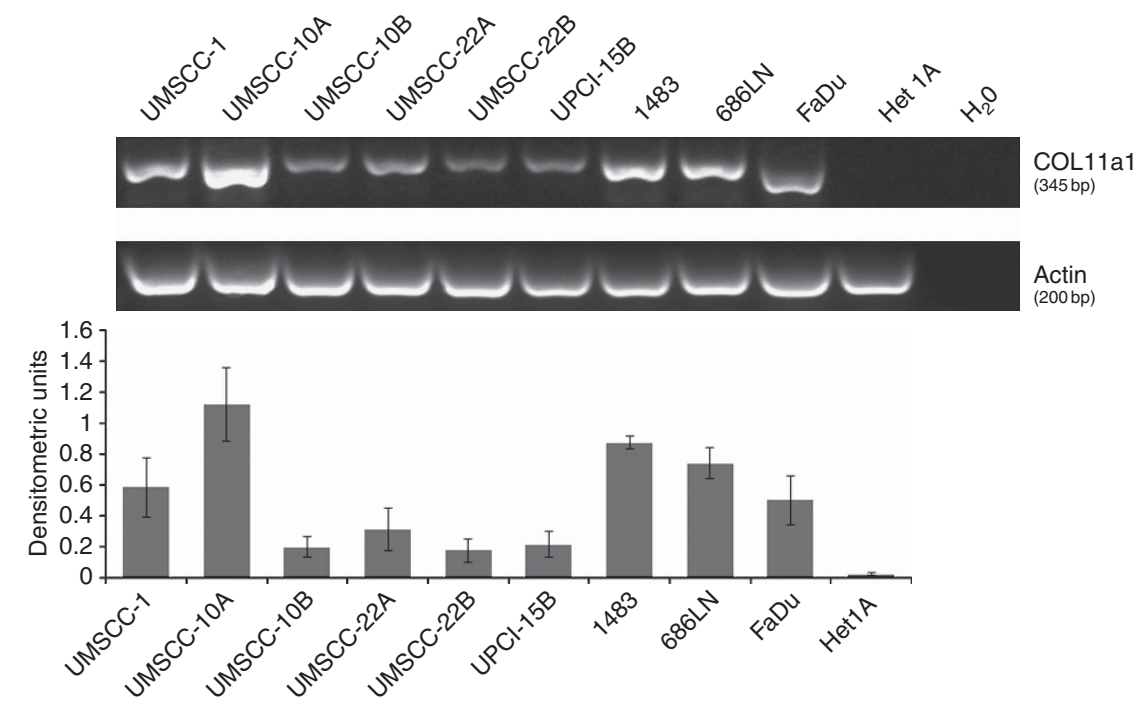

Figure 2. Increased expression of colXI $\alpha 1$ in $\mathrm{HNSCC}$ cell lines compared with normal immortalised mucosal epithelial cells. ColXI 1 mRNA levels were examined in nine representative HNSCC cell lines (UMSCC-1, UMSCC-10A, UMSCC-10B, UMSCC-22A, UMSCC-22B, UPCI-15B, 1483, $686 \mathrm{LN}$, and FaDu) by RT-PCR. Expression of colXl $\alpha 1$ was increased in all nine cell lines compared with immortalised normal mucosal epithelial cells (Het1A). The experiment was repeated twice with similar results.

expression of colXI $\alpha 1$ is associated with malignancy in colorectal cancer (Fischer et al, 2001b). Higher levels of colXI $\alpha 1$ were reported in fibroblasts associated with lung cancer compared with normal fibroblasts (Navab et al, 2011). HNSCC tumours are closely associated with fibroblasts. There are no reports on the levels of $\operatorname{colXI} \alpha 1$ expressed by stromal fibroblasts in the head and neck region. Primary HNSCC cancer-associated fibroblasts and fibroblasts from cancer-free subjects were grown out of tissue explants. We examined the levels of colXI $\alpha 1$ in primary fibroblasts isolated from cancer-free patients and HNSCC explants. Our data demonstrate that the cancer-associated fibroblast express higher levels of colXI $\alpha 1$ compared with fibroblasts from cancer-free patients (Figure 3).

ColXI $\alpha 1$ contributes to HNSCC proliferation, migration, and invasion. Although colXI $\alpha 1$ has been shown to correlate with tumour size in non-small cell lung cancer (Chong et al, 2006), the role of colXI $\alpha 1$ in cell growth has not been examined in cancer cells. We hypothesised that, if $\operatorname{colXI} \alpha 1$ contributes to HNSCC proliferation, then knocking down colXI $\alpha 1$ with siRNA would decrease cell proliferation in vitro. We transfected HNSCC cells with pooled siRNA targeting colXI $\alpha 1$ or GFP as a control, collected cells on days 2, 3, 4, and 5, and performed RT-PCR. Gene inactivation was observed on day 5 (Figure 4A). Next, we tested individual siRNA and determined that siRNA B demonstrated efficient knockdown of colXI $\alpha 1$ up to $48 \mathrm{~h}$ post transfection (Figure 4B).

The growth kinetics of cells transfected with siRNA- colXI $\alpha 1$ duplex B was compared with cells transfected with non-targeting siRNA. colXI $\alpha 1$ on transfection with siRNA duplex B significantly reduced cell proliferation compared with cells transfected with non-targeting control siRNA $(P=0.014)$ (Figure 5A). These results suggest that $\operatorname{colXI} \alpha 1$ contributes to cell proliferation in HNSCC cells in vitro.

ColXI $\alpha 1$ expression has been reported to be 7.61-fold higher in the primary HNSCC tumour in the setting of metastasis to the 


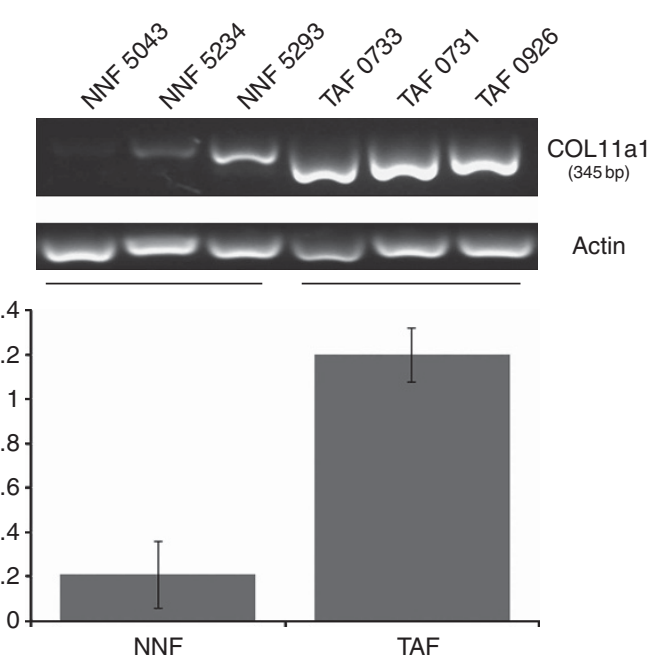

Figure 3. Increased expression of colXl $\alpha 1$ in tumour-derived fibroblasts compared with normal fibroblasts. Primary cancerassociated fibroblasts (TAF) isolated from HNSCC and fibroblasts isolated from oral mucosa of cancer-free patients (NNF) were assessed for colXl $\alpha 1$ mRNA levels by RT-PCR. Expression of colXl $\alpha 1$ was higher in the TAF lines compared with the NNF lines.
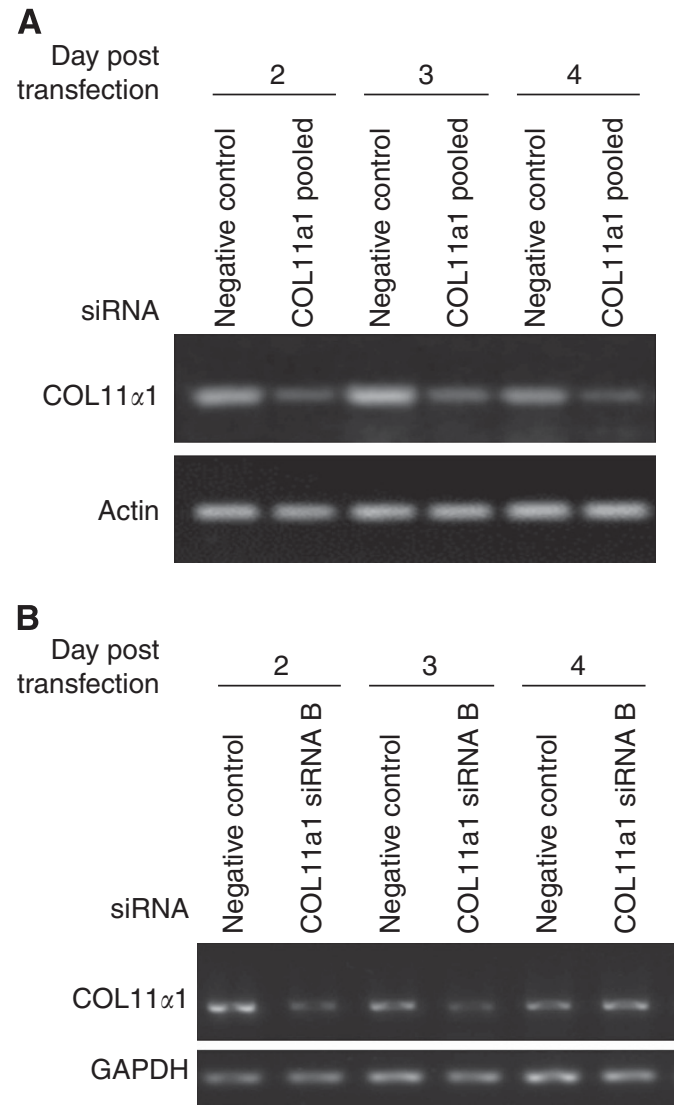

Figure 4. ColXI $\alpha 1$ siRNA effectively reduces mRNA levels of colXl $\alpha 1$. (A) HNSCC cells were transfected with pooled siRNA-targeted against the colXl $\alpha 1$ gene or with control siRNA, which does not share sequences with the colXI 1 gene. Cells were collected on days 2, 3, 4 , and 5 and subjected to RT-PCR. Maximum gene inactivation was observed on day 5. RT-PCR amplification of the $\beta$-actin gene (lower panel) was used in each sample to monitor RNA levels and nonspecific RNA template degradation. (B) Cells were transfected with colXl $\alpha 1$ duplex $B$ siRNA. Efficient knockdown of colXl $\alpha 1$ was achieved up to 3 days post transfection. lymph nodes compared with levels in a primarily HNSCC tumour that remains confined to the head and neck mucosa (Schmalbach et al, 2004). The role of colXI $\alpha 1$ in cell migration or invasion has not been studied. To determine if $\operatorname{colXI} \alpha 1$ contributes to HNSCC migration in vitro, representative HNSCC cell lines (UMSCC-1 and FaDu) were transfected with colXI $\alpha 1$ duplex B siRNA or the non-targeting control siRNA (siRNA-NTC). We also assessed invasion using a Boyden Matrigel chamber assay. ColXI $\alpha 1$ knockdown in UMSCC-1 and FaDu cells resulted in reduced migration $(P=0.05)$ and invasion $(P=0.05)$, respectively (Figure $5 \mathrm{~B}$ and $\mathrm{C}$ ). Thus, colXI $\alpha 1$ is an important facilitator of HNSCC progression.

\section{DISCUSSION}

Type XI collagen, a minor fibril collagen, is a heterotrimer made up of a1(XI)-, a2(XI)-, and a3(XI) chains (Yoshioka et al, 1995) and accounts for $\sim 3 \%$ of the adult cartilage matrix (Eyre et al, 2006). Molecules of collagen IX and XI stabilise collagen II, a major collagen, and limit its lateral growth (Blaschke et al, 2000). The role of type XI collagen in the adult remains unclear, although recent evidence in numerous types of cancer implicates colXI $\alpha 1$ in carcinogenesis (Vecchi et al, 2007; Badea et al, 2008; Ellsworth et al, 2009; Kim et al, 2010). Further, expression of colXI $\alpha 1$ is reported to be accompanied expression of genes associated with epithelial-to-mesenchymal transition (EMT) (Anastassiou et al, 2011).

We previously reported that $\operatorname{colXI} \alpha 1$ was present in tumour tissue and was undetectable in corresponding normal adjacent tissue in a cDNA microarray analysis of tissue from nine HNSCC patients (Sok et al, 2003). Microarray of paired tumour and normal tissue from 36 patients with pancreatic ductal adenocarcinoma revealed greater than two-fold overexpression of $\operatorname{colXI} \alpha 1$ in tumour tissue compared with normal tissue (Badea et al, 2008). RT-PCR of paired tumour and normal tissue from 70 pairs of patients with non-small cell carcinoma demonstrated 3.4-fold higher expression of colXI $\alpha 1$ in tumour tissue (Chong et al, 2006). Similarly, RT-PCR of paired malignant and premalignant tissue from 21 patients with gastric cancer showed increased levels of colXI $\alpha 1$ in malignant tissue (Zhao et al, 2009), and RT-PCR of polyps and normal tissue from 1 patient with familial adenomatous polyposis showed increased colXI $\alpha 1$ expression in the polyps (Fischer et al, 2001a). Most of the reports on colXI $\alpha 1$ in cancer represent correlative studies; thus, to our knowledge, this is the first investigation of the functional significance of $\operatorname{colXI} \alpha 1$ overexpression in any type of cancer.

Collagens in general are important components of the extracellular matrix. It has been shown that collagen cross linking increases ECM stiffness and promotes tumorigenesis in breast cancer and that reduction in collagen cross linking leads to a decrease in tumour incidence (Blaschke et al, 1994). We undertook the present study to determine the role of colXI $\alpha 1$ in proliferation, migration, and invasion of head and neck cancer. Our results suggest that colXI $\alpha 1$ expression is increased in HNSCC tumours and cell lines compared with levels in normal tissue or immortalised epithelial cells. Further investigation demonstrated that $\operatorname{colXI} \alpha 1$ contributes to the proliferation, migration, and invasion of head and neck cancer cells in vitro.

HNSCC carcinogenesis is characterised by a high incidence of synchronous and metachronous tumours, suggesting that molecular changes that are found in both the tumour and adjacent normal mucosa represent relatively early genetic changes (Bedi et al, 1996; Scholes et al, 1998). In this study, we found that colXI $\alpha 1$ expression by RT-PCR was higher in tumour compared with normal tissue in paired samples in 16 of 23 

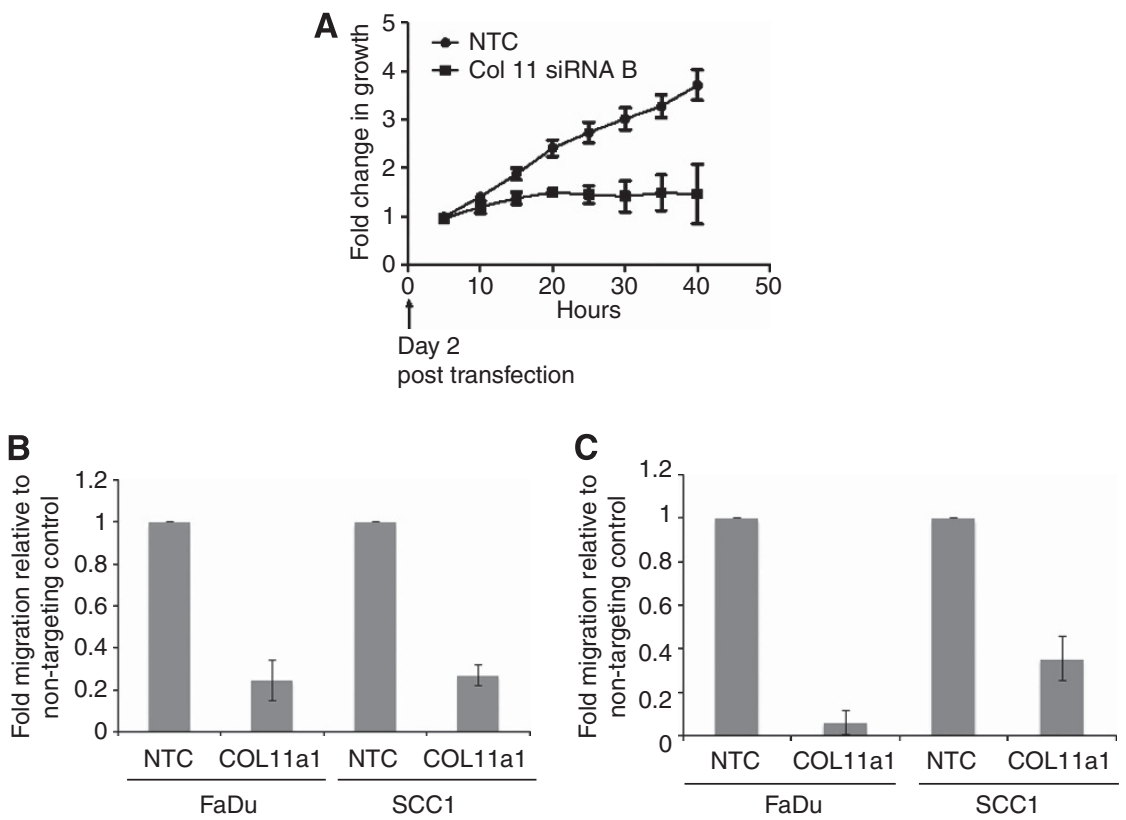

Figure 5. ColXI $\alpha 1$ contributes to HNSCC proliferation, migration, and invasion. (A) HNSCC cells UMSCC-1 were transfected with non-targeting control siRNA (NTC) or colXI 1 siRNA. Cells were plated on day 2 post transfection, in the xCelligence DP E-plate and assessed for cell growth in real-time over $40 \mathrm{~h}$. The cells were treated in quadruplicates. The line graph depicts cumulative data from four separate experiments. Error bars represent \pm s.e.m. UMSCC-1 and FaDu cells transfected with siRNA-colXl $\alpha 1$ duplex B or non-targeting control siRNA (NTC) was determined using a Boyden chamber (B) migration and (C) invasion assay. Migrated cells were counted $24 \mathrm{~h}$ post plating in four separate fields. Cumulative results are shown for wells treated in triplicate from three independent experiments $(P=0.05)$. Error bars represent \pm s.e.m. (C) The invasion of UMSCC-1 and FaDu cells transfected with siRNA-colXl $\alpha 1$ duplex B compared with cells transfected with non-targeting control siRNA (siRNA-NTC) was determined using a Boyden chamber Matrigel assay. Cumulative results from three independent experiments demonstrate a significant reduction in HNSCC invasion up on colXI $\alpha 1$ siRNA treatment compared with the NTC siRNA control $(P=0.05)$.

HNSCC patients, indicating that increased colXI $\alpha 1$ expression is a later event in HNSCC carcinogenesis. Our findings are consistent with previous findings of increased colXI $\alpha 1$ in tumour compared with normal tissue in paired samples from 70 patients with nonsmall cell lung carcinoma and in malignant tissue compared with pre-malignant tissue in paired specimens from 21 patients with gastric cancer (Zhao et al, 2009). Our attempts at generating a polyclonal antibody to $\operatorname{colXI} \alpha 1$ were not successful primarily because of the paucity of unique antigenic epitopes. Lack of specific antibodies limited our ability to assess protein levels of $\operatorname{colXI} \alpha 1$ in tissue and cell lines.

Because changes in the stromal tumour microenvironment are thought to contribute to invasion and spread of tumours (De Wever and Mareel, 2003), we compared the expression levels of colXI $\alpha 1$ in cancer-associated fibroblasts and normal oral fibroblasts derived from cancer-free patients. We found that cancer-associated fibroblasts had higher levels of colXI $\alpha 1$ compared with normal oral fibroblasts. The cancer-associated fibroblasts and normal oral fibroblasts used in these studies were primary cells derived from fresh tissue. These cells are cultured for up to 10 passages and retain their fibroblast morphology. However, it cannot be ruled out that HNSCC cells that have undergone epithelial-to-mesenchymal transition are present among the cancer-associated fibroblast cultures. The data suggest that changes in mesenchymal cells in the HNSCC microenvironment are associated with increased levels of $\operatorname{colXI} \alpha 1$, a finding that is at odds with Halsted et al (2008), who found that $\operatorname{colXI} \alpha 1$ was downregulated in stroma surrounding breast cancer. In another study of breast cancer, however, higher levels of colXI $\alpha 1$ expression in primary breast tumours than in corresponding metastatic lymph node tumours were reported and concluded that the overexpression of genes in the primary tumours were involved with extracellular matrix degradation and contributed to metastatic spread of the tumour (Ellsworth et al, 2009). Further, it has been proposed that interaction between breast and colon cancer cells with the microenvironment triggers expression of mesenchymal signature genes including colXI $\alpha 1$ (Cheng et al, 2013).

We sought to determine if increased $\operatorname{colXI} \alpha 1$ expression was derived from the transformed epithelial cells and/or stromal cells in the tumour microenvironment. To date, there is no literature on colXI $\alpha 1$ expression in cancer cell lines compared with normal cells. We compared colXI $\alpha 1 \mathrm{mRNA}$ levels in nine validated, representative HNSCC cell lines using RT-PCR and found that expression was increased in all nine HNSCC cell lines, whereas the corresponding normal cells did not express the colXI $\alpha 1$ transcript. Thus we conclude that both the tumour and stromal fibroblast cells contribute to the high levels of collXI $\alpha 1$ in HNSCC tissue.

Although studies of gastric, lung, ovarian, and colorectal carcinomas have implicated the role of $\operatorname{colXI} \alpha 1$ overexpression in more advanced disease (Schmalbach et al, 2004; Vecchi et al, 2007; Zhao et al, 2009; Kim et al, 2010), only one study has correlated $\operatorname{colXI} \alpha 1$ and tumour size (Chong et al, 2006). Further, no direct investigation has been undertaken to examine the role of $\operatorname{colXI} \alpha 1$ in cellular proliferation of cancerous or normal cells. We postulated that by knocking down colXI $\alpha 1$ in HNSCC cells in vitro, proliferation would decrease. We transfected a representative HNSCC cell line (UMSCC-1) with siRNA directed against $\operatorname{colXI} \alpha 1$ and demonstrated decreased $\operatorname{colXI} \alpha 1$ expression by RT-PCR. We then demonstrated that cellular proliferation of UMSCC- 1 cells decreased in the siRNA-colXI $\alpha 1$-transfected cells in comparison with the control. In contrast, normal Het1A cells did not display a decrease in proliferation after transfection with siRNA-colXI $\alpha 1$. Therefore, these results suggest that $\operatorname{colXI} \alpha 1$ overexpression does, in fact, contribute to cellular proliferation in cancer cells and that knockdown of $\operatorname{colXI} \alpha 1$ abrogates cell growth in cancer cells but not normal cells. 
ColXI $\alpha 1$ has been implicated in metastasis, with one study demonstrating higher levels of colXI $\alpha 1$ in primary tumours of the head and neck that have metastasised to the lymph node compared with tumours that remain confined to the primary site (Schmalbach et al, 2004). Cellular migration and invasion are thought to contribute to metastasis. No studies to date have examined the role of colXI $\alpha 1$ on cell motility of any type. We assessed the role of colXI $\alpha 1$ in invasion and migration in UMSCC-1 and Het1A cells that had been transfected with siRNA$\operatorname{colXI} \alpha 1$. We demonstrated that knocking down colXI $\alpha 1$ decreases migration and invasion in the HNSCC cell lines UMSCC-1 but not in the normal cell line Het1A. Thus, colXI $\alpha 1$ not only contributes to proliferation but also to invasion and migration as well in cancer cells, with no effect on normal cells.

Patients with HNSCC, like many epithelial cancers, succumb to disease that has metastasised. The precise mechanisms of HNSCC metastasis, including migration and invasion remain incompletely understood. The results of the present study suggest that $\operatorname{colXI} \alpha 1$ has a role in mediating the proliferation, invasion, and migration of cancer cells, underscoring the need for further investigation of this collagen in carcinogenesis.

\section{ACKNOWLEDGEMENTS}

This work was supported by the AAO Maureen Hannley Research Traning Award (JS), the Doris Duke Charitable Foundation (JL), T32 DC000066 (JL), and the SPORE in Head and Neck Cancer P50CA097190 (SMT and JRG), School of Medicine, Kansas University Medical Center (SMT).

\section{REFERENCES}

Anastassiou D, Rumjantseva V, Cheng W, Huang J, Canoll PD, Yamashiro DJ, Kandel JJ (2011) Human cancer cells express Slug-based epithelialmesenchymal transition gene expression signature obtained in vivo. BMC Cancer 11: 529.

Badea L, Herlea V, Dima SO, Dumitrascu T, Popescu I (2008) Combined gene expression analysis of whole-tissue and microdissected pancreatic ductal adenocarcinoma identifies genes specifically overexpressed in tumor epithelia. Hepatogastroenterology 55(88): 2016-2027.

Bedi GC, Westra WH, Gabrielson E, Koch W, Sidransky D (1996) Multiple head and neck tumors: evidence for a common clonal origin. Cancer Res 56(11): 2484-2487.

Blaschke RJ, Howlett AR, Desprez PY, Petersen OW, Bissell MJ (1994) Cell differentiation by extracellular matrix components. Methods Enzymol 245: 535-556.

Blaschke UK, Eikenberry EF, Hulmes DJ, Galla HJ, Bruckner P (2000) Collagen XI nucleates self-assembly and limits lateral growth of cartilage fibrils. J Biol Chem 275(14): 10370-10378.

Bonner JA, Harari PM, Giralt J, Azarnia N, Shin DM, Cohen RB, Jones CU, Sur R, Raben D, Jassem J, Ove R, Kies MS, Baselga J, Youssoufian H, Amellal N, Rowinsky EK, Ang KK (2006) Radiotherapy plus Cetuximab for Squamous-Cell Carcinoma of the Head and Neck. New Engl J Med 354(6): 567-578.

Cheng WY, Ou Yang TH, Anastassiou D (2013) Biomolecular events in cancer revealed by attractor metagenes. PLoS Comput Biol 9(2): e1002920.

Chong I-W, Chang M-Y, Chang H-C, Yu Y-P, Sheu C-C, Tsai J-R, Hung J-Y, Chou S-H, Tsai M-S, Hwang J-J, Lin S-R (2006) Great potential of a panel of multiple hMTH1, SPD, ITGA11 and COL11A1 markers for diagnosis of patients with non-small cell lung cancer. Oncol Rep 16(5): 981-988.

Cognetti DM, Weber RS, Lai SY (2008) Head and neck cancer - an evolving treatment paradigm. Cancer 113(7): 1911-1932.

De Wever O, Mareel M (2003) Role of tissue stroma in cancer cell invasion. $J$ Pathol 200(4): 429-447.

Ellsworth RE, Seebach J, Field LA, Heckman C, Kane J, Hooke JA, Love B, Shriver CD (2009) A gene expression signature that defines breast cancer metastases. Clin Exp Metastasis 26(3): 205-213.
Eyre DR, Weis MA, Wu JJ (2006) Articular cartilage collagen: an irreplaceable framework? Eur Cell Mater 12: 57-63.

Ferlay J, Shin H, Bray F, Forman D, Mathers C, Parkin D. GLOBOCAN (2008) Cancer Incidence and Mortality Worldwide: IARC CancerBase No. 10 [Internet]. International Agency for Research on Cancer; 2010: Lyon, France. Available from http://globocan.iarc.fr.

Fischer H, Salahshor S, Stenling R, Bjork J, Lindmark G, Iselius L, Rubio C, Lindblom A (2001a) COL11A1 in FAP polyps and in sporadic colorectal tumors. BMC cancer 1: 17 .

Fischer H, Stenling R, Rubio C, Lindblom A (2001b) Colorectal carcinogenesis is associated with stromal expression of COL11A1 and COL5A2. Carcinogenesis 22(6): 875-878.

Grenman R, Carey TE, McClatchey KD, Wagner JG, Pekkola-Heino K, Schwartz DR, Wolf GT, Lacivita LP, Ho L, Baker SR (1991) In vitro radiation resistance among cell lines established from patients with squamous cell carcinoma of the head and neck. Cancer 67(11): 2741-2747.

Halsted KC, Bowen KB, Bond L, Luman SE, Jorcyk CL, Fyffe WE, Kronz JD, Oxford JT (2008) Collagen alpha1(XI) in normal and malignant breast tissue. Mod Pathol 21(10): 1246-1254.

Hickok JR, Sahni S, Mikhed Y, Bonini MG, Thomas DD (2011) Nitric oxide suppresses tumor cell migration through $\mathrm{N}-\mathrm{Myc}$ downstream-regulated gene-1 (NDRG1) expression: role of chelatable iron. J Biol Chem 286(48): 41413-41424.

Kim H, Watkinson J, Varadan V, Anastassiou D (2010) Multi-cancer computational analysis reveals invasion-associated variant of desmoplastic reaction involving INHBA, THBS2 and COL11A1. BMC Med Genomics 3 : $51-62$.

Krause CJ, Carey TE, Ott RW, Hurbis C, McClatchey KD, Regezi JA (1981) Human squamous cell carcinoma. Establishment and characterization of new permanent cell lines. Arch Otolaryngol 107(11): 703-710.

Lansford CGR, Bier H, Somers KD, Kim SY, Whiteside TL, Clayman G, Carey TE (1999) Head and neck cancers. In: Masters JR, Palsson B (eds.) Human cell culture. Vol 2, pp 185-255. Kluwer Academic Publishers: Dordrecht.

Navab R, Strumpf D, Bandarchi B, Zhu CQ, Pintilie M, Ramnarine VR, Ibrahimov E, Radulovich N, Leung L, Barczyk M, Panchal D, To C, Yun JJ, Der S, Shepherd FA, Jurisica I, Tsao MS (2011) Prognostic gene-expression signature of carcinoma-associated fibroblasts in nonsmall cell lung cancer. Proc Natl Acad Sci USA 108(17): 7160-7165.

Rangan SR (1972) A new human cell line (FaDu) from a hypopharyngeal carcinoma. Cancer 29(1): 117-121.

Rubin Grandis J, Tweardy DJ, Melhem MF (1998) Asynchronous modulation of transforming growth factor alpha and epidermal growth factor receptor protein expression in progression of premalignant lesions to head and neck squamous cell carcinoma. Clinical Cancer Res 4(1): 13-20.

Sacks PG, Parnes SM, Gallick GE, Mansouri Z, Lichtner R, Satya-Prakash KL, Pathak S, Parsons DF (1988) Establishment and characterization of two new squamous cell carcinoma cell lines derived from tumors of the head and neck. Cancer Res 48(10): 2858-2866.

Schmalbach CE, Chepeha DB, Giordano TJ, Rubin MA, Teknos TN, Bradford CR, Wolf GT, Kuick R, Misek DE, Trask DK, Hanash S (2004) Molecular profiling and the identification of genes associated with metastatic oral cavity/pharynx squamous cell carcinoma. Arch Otolaryngol Head Neck Surg 130(3): 295-302.

Scholes AGM, Woolgar JA, Boyle MA, Brown JS, Vaughan ED, Hart CA, Jones AS, Field JK (1998) Synchronous oral carcinomas: independent or common clonal origin? Cancer Res 58(9): 2003-2006.

Snyderman CH, Klapan I, Milanovich M, Heo DS, Wagner R, Schwartz D, Johnson JT, Whiteside TL (1994) Comparison of in vivo and in vitro prostaglandin E2 production by squamous cell carcinoma of the head and neck. Otolaryngology Head Neck Surg 111(3 Pt 1): 189-196.

Sok JC, Coppelli FM, Thomas SM, Lango MN, Xi S, Hunt JL, Freilino ML, Graner MW, Wikstrand CJ, Bigner DD, Gooding WE, Furnari FB, Grandis JR (2006) Mutant epidermal growth factor receptor (EGFRvIII) contributes to head and neck cancer growth and resistance to EGFR targeting. Clin Cancer Res 12(17): 5064-5073.

Sok JC, Kuriakose MA, Mahajan VB, Pearlman AN, DeLacure MD, Chen F-A (2003) Tissue-specific gene expression of head and neck squamous cell carcinoma in vivo by complementary DNA microarray analysis. Arch otolaryngol Head Neck Surg 129(7): 760-770.

Somers KD, Merrick MA, Lopez ME, Incognito LS, Schechter GL, Casey G (1992) Frequent p53 mutations in head and neck cancer. Cancer Res 52(21): 5997-6000. 
Spranger J (1998) The type XI collagenopathies. Pediatr Radiol 28(10): $745-750$.

Stoner GD, Kaighn ME, Reddel RR, Resau JH, Bowman D, Naito Z, Matsukura N, You M, Galati AJ, Harris CC (1991) Establishment and characterization of SV40 T-antigen immortalized human esophageal epithelial cells. Cancer Res 51(1): 365-371.

Sturgis EM, Sacks PG, Masui H, Mendelsohn J, Schantz SP (1994) Effects of antiepidermal growth factor receptor antibody 528 on the proliferation and differentiation of head and neck cancer. Otolaryngol Head Neck Surg 111(5): 633-643.

Vecchi M, Nuciforo P, Romagnoli S, Confalonieri S, Pellegrini C, Serio G, Quarto M, Capra M, Roviaro GC, Contessini Avesani E, Corsi C, Coggi G, Di Fiore PP, Bosari S (2007) Gene expression analysis of early and advanced gastric cancers. Oncogene 26(29): 4284-4294.
Yoshioka H, Greenwel P, Inoguchi K, Truter S, Inagaki Y, Ninomiya Y, Ramirez F (1995) Structural and functional analysis of the promoter of the human 1(XI) collagen gene. J Biol Chem 270(1): 418-424.

Zhao Y, Zhou T, Li A, Yao H, He F, Wang L, Si J (2009) A potential role of collagens expression in distinguishing between premalignant and malignant lesions in stomach. Anat Rec(Hoboken) 292(5): 692-700.

This work is published under the standard license to publish agreement. After 12 months the work will become freely available and the license terms will switch to a Creative Commons AttributionNonCommercial-Share Alike 3.0 Unported License. 